\title{
Interaksi Indeks Dow Jones, Kurs Dolar, Minyak Dunia, Emas dan Indeks Saham Indonesia LQ45
}

\author{
Muh. Irfandy Azis1*, Sabrang Gilang Gemilang2", Dzulfikri Azis Muthalib3* \\ "Universitas Borneo Tarakan \\ Jurusan Akuntansi \\ Tarakan, Kalimantan Utara, Indonesia \\ E-mail: muh.irfandyazis@gmail.com \\ \#Universitas Islam Negeri Mataram \\ Jurusan Tadris IPS \\ Mataram, Nusa Tenggara Barat, Indonesia \\ E-mail: sabrang@uinmataram.ac.id \\ *STIE-66 Kendari \\ Jurusan Manajemen \\ Kendari, Sulawesi Tenggara, Indonesia \\ E-mail: dzulfikriazisstie66@gmail.com
}

\begin{abstract}
Abstrak
Tujuan penelitian ini adalah mengetahui pengaruh jangka pendek dan jangka panjang serta hubungan kausalitas dua arah antara Indeks Saham Dow Jones, nilai tukar Rupiah terhadap Dolar atau Kurs Dolar, harga Minyak Dunia dan harga Emas Dunia terhadap Indeks Saham Indonesia LQ45. Jenis data yang digunakan untuk mencapai tujuan penelitian tersebut adalah data runtun waktu atau time series dengan data harian mulai dari tanggal 1 Januari 2010 sampai dengan 31 Desember 2019. Data diolah dengan menggunakan aplikasi e-views, sehingga hasil cointegration test menunjukkan bahwa terdapat hubungan kointegrasi pada setiap variabel penelitian yang dapat diartikan terdapat pengaruh jangka panjang antara Indeks Dow Jones, Kurs Dolar, Minyak Dunia dan Emas terhadap Indeks Saham Indonesia LQ45. Berdasarkan hasil uji kausalitas granger, menunjukkan bahwa terdapat hubungan kausalitas dua arah antara Kurs Dolar dan Emas terhadap Indeks Saham Indonesia LQ45. Sedangkan Indeks Dow Jones dan Minyak Dunia hanya memiliki hubungan satu arah terhadap variabel Indeks Saham Indonesia LQ45. Selain itu, berdasarkan hasil analisis impulse response dengan mengambil sepuluh periode pengamatan diperoleh hasil bahwa pada awal periode pengamatan terdapat pengaruh yang besar kemudian semakin kecil seiring bertambahnya periode pengamatan akan tetapi tetap memiliki pengaruh pada setiap variabel penelitian. Artinya yaitu terdapat pengaruh jangka panjang antara Indeks Dow Jones, Kurs Dolar, Minyak Dunia dan Emas terhadap Indeks Saham Indonesia LQ45.
\end{abstract}

Kata kunci: Indeks Dow Jones, Kurs Dolar, Minyak Dunia, Emas, Indeks LQ45

\begin{abstract}
This study aims to determine the short-term effect, long-term effect and causality effect between the Dow Jones Index, Dollar Exchange Rate, Crude Oil WTI and Gold on the Indonesian Stock Index LQ45. The type of data used to achieve the research objectives is time series data with daily data starting from January 1, 2010 to December 31 , 2019. The data is processed using the e-views application, so the results of the cointegration test show that there is a cointegration relationship in each research variable can be interpreted that there is a long-term effect between the Dow Jones Index, Dollar Exchange Rate, Crude Oil WTI and Gold on the Indonesian Stock Index LQ45. Based on the results of the Granger causality test, it shows that there is a two-way causality effect between the Dollar Exchange Rate and Gold against the Indonesian Stock Index LQ45. Whereas the Dow Jones Index and Crude Oil WTI only have a one-way effect to the Indonesian Stock Index LQ45. In addition, based on the results of the impulse response analysis by taking ten observation periods, it was found that at the beginning of the observation period there was a large effect then it got smaller as the observation period increased but still had an effect on each research variable. This means that there is a long-term effect between the Dow Jones Index, Dollar Exchange Rate, Crude Oil WTI and Gold on the Indonesian Stock Index LQ45.
\end{abstract}

Keywords: Dow Jones Index, Dollar Exchange Rate, Crude Oil WTI, Gold, LQ45 Index 


\section{Pendahuluan}

Ukuran kondisi perekonomian suatu negara dapat dilihat salah satunya melalui kondisi pasar modal. Buruknya kondisi pasar modal suatu negara bisa menjadi indikasi bahwa perekonomian negara tersebut sudah sedang mengalami keterpurukan, sebaliknya jika kondisi pasar modal baik maka bisa menjadi indikasi bahwa perekonomian sedang berada dalam kondisi yang baik.

Semakin meratanya literasi keuangan masyarakat tentang pasar modal, sejalan dengan peningkatan keinginan untuk berinvestasi. Secara umum keputusan investasi pada pasar modal dipengaruhi oleh dua faktor yaitu harapan mendapat keuntungan dan kekhawatiran terhadap resiko kerugian yang mungkin terjadi. Sebagian investor berani untuk mengambil resiko tinggi dengan harapan untuk mendapat keuntungan yang tinggi pula (Pradikasari \& Isbanah, 2018). Sebagian Investor memiliki toleransi yang tinggi terhadap kemungkinan resiko yang mungkin terjadi (Budiarto, 2017).

Indeks Harga Saham Gabungan (IHSG) yang merupakan indeks saham utama Indonesia dimana terdapat banyak pilihan saham untuk investor. Selain IHSG, Indonesia memiliki indeks saham lain, seperti indeks saham LQ45, indeks saham syariah JKII dan indeks saham sector industri. Indeks saham yang paling terkenal dan paling banyak diminati setelah IHSG adalah indeks saham LQ45, karena perusahaan anggota indeks saham LQ45 memiliki reputasi yang baik dari segi nilai pasar, nilai transaksi dan kondisi fundamental perusahaan. Oleh karena itu, dapat menjadi pilihan investor untuk berinvestasi di pasar modal.

Kinerja portofolio saham indeks LQ45 melalui strategi aktif maupun pasif, menunjukkan bahwa terdapat perbedaan signifikan dari kedua strategi tersebut. Kinerja portofolio melalui strategi aktif maupun pasif, keduanya menunjukkan kinerja yang positif dimana tingkat imbal hasil atau return yang didapat jauh lebih besar dari risiko yang dihadapi (Larasati et al., 2016). Kinerja portofolio optimal pada saham indeks LQ45, menunjukkan bahwa imbal hasil atau return saham sejalan dengan resiko. Semakin tinggi imbal hasil atau return saham yang diharapkan, semakin tinggi potensi resikonya (Ismanto, 2016).

Volatilitas pasar saham khususnya volatilitas indeks saham LQ45, sehingga investor perlu memperhatikan sebelum memutuskan berinvestasi di pasar saham Indonesia. Volatilitas penting karena bisa memprediksi return saham dan resiko investasi. Dengan tingkat volatilitas yang semakin tinggi, imbal hasil atau return saham yang kemungkinan didapatkan akan semakin tinggi pula. Begitupun dengan resiko yang akan dihadapi, maka akan semakin tinggi (Rohmawati, 2017). Return saham dapat menyebabkan terjadinya volatilitas indeks saham LQ45, atau dapat artikan bahwa return saham dan volatilitas indeks saham LQ45 sebelumnya mempengaruhi volatiltas periode saat ini. Dengan memperhatikan hal tersebut, investor bisa mengambil langkah kehati-hatian jika terjadi sentimen negatif pada pasar modal karena mengindikasikan peningkatan resiko investasi (Wulansari \& Yonnedi, 2015). Berikut adalah volatilitas indeks saham LQ45 selama 10 tahun dimulai dari awal Januari 2010 sampai dengan akhir Desember 2019:

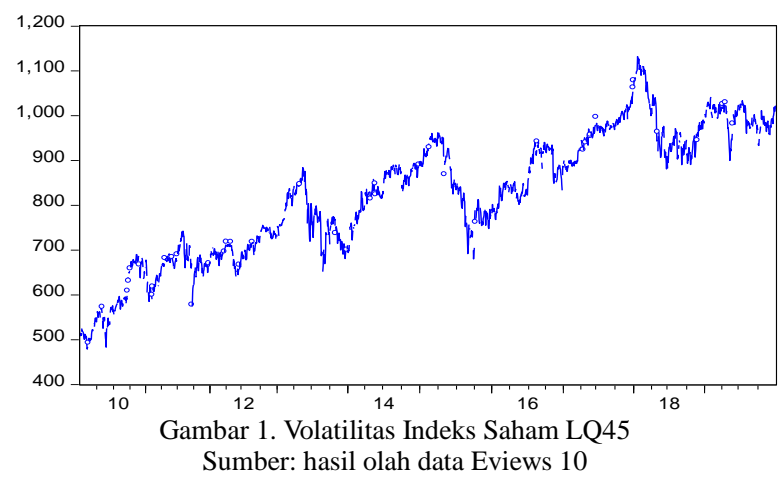

Berdasarkan gambar 1 di atas, menunjukkan bahwa tingkat volatilitas indeks saham LQ45 cukup tinggi pada kurun waktu 1 Januari 2010 sampai 31 Desember 2019. Selain itu indeks saham LQ45 juga mengalami trend peningkatan yang tinggi. Selama 10 tahun, indeks saham LQ45 meningkat $100 \%$. Secara umum peningkatan harga pada indeks saham dipengaruhi oleh beberapa faktor yaitu indeks saham yang lain, kurs nilai tukar rupiah, komoditas dunia, logam mulia dan makro ekonomi.

Menurut Jannah \& Nurfauziah (2018), nilai tukar rupiah terhadap dolar atau dalam hal ini adalah kurs dolar dan harga emas dunia memiliki pengaruh yang positif dan signifikan terhadap indeks saham LQ45. Hal tersebut dikarenakan perusahaan yang termasuk kedalam indeks saham LQ45 lebih berorientasi terhadap ekspor, sehingga dengan pasti kurs dolar akan mempengaruhi indeks saham LQ45 secara positif. Selain itu, harga emas yang mempengaruhi indeks saham LQ45 disebabkan karena emas sering dijadikan lindung nilai untuk mengurangi resiko pada portofolio investasi. Sedangkan menurut Untono (2015), Indeks Saham Dow Jones memiliki pengaruh positif dan signifikan terhadap Indeks Harga Saham Gabungan (IHSG) yang disebabkan oleh karena tujuan ekspor utama bagi perusahaan di Indonesia salah satunya adalah Amerika Serikat, sehingga perekonomian Amerika Serikat yang ditunjukkan oleh Indeks Saham Dow Jones memiliki pengaruh yang cukup signifikan terhadap IHSG. Selain itu, berdasarkan hasil penelitian Antonius (2019) juga menunjukkan bahwa Indeks Saham Dow Jones berpengaruh positif dan signifikan terhadap indeks saham sektoral di Indonesia. Beberapa sektor industri perusahaan di Indonesia juga memiliki hubungan perdagangan dengan perusahaan di Amerika 
Serikat, sehingga besar kemungkinan harga saham sektor industri juga dipengaruhi oleh Indeks Saham Dow Jones.

Sebaliknya, berdasarkan penelitian Syarif \& Asandimitra (2015) menunjukkan bahwa kurs dolar berpengaruh negatif dan signifikan terhadap IHSG. Hal ini disebabkan kondisi ekonomi yang buruk dan menyusul penguatan nilai kurs dolar terhadap rupiah. Kondisi sebaliknya dari harga emas dunia yang tidak memiliki pengaruh signifikan terhadap IHSG. Hal tersebut dikarenakan emas merupakan jenis investasi jangka panjang sementara investor di Indonesia cenderung untuk melakukan transaksi jual beli saham dalam jangka waktu yang pendek atau biasa disebut trader. Selain itu, hasil penelitian Syarif \& Asandimitra (2015) menunjukkan harga minyak dunia memiliki pengaruh yang positif dan signifikan terhadap IHSG. Hal tersebut dikarenakan kenaikkan harga minyak dunia dapat dimanfaatkan oleh beberapa perusahaan di Indonesia khususnya disektor pertambangan yang bergerak pada bidang eksplorasi minyak untuk mendapat keuntungan lebih sehingga berdampak pada peningkatan harga saham perusahaan. Penelitian Antonius (2019) juga menunjukkan bahwa harga minyak dunia dan nilai kurs dolar berpengaruh negatif dan signifikan terhadap indeks saham sectoral Indonesia.

Beberapa penelitian yang dilakukan sebelumnya menggunakan teknik analisis regresi berganda untuk menganalisis faktor-faktor yang mempengaruhi harga saham pada indeks saham Indonesia. Berbeda dengan penelitian ini, teknik analisis yang digunakan dalam penelitian ini adalah analisis deret waktu atau analisis time series. Penelitian ini tidak hanya berfokus pada pengaruh langsung tetapi terbagi menjadi tiga fokus penelitian yaitu pengaruh jangka pendek, pengaruh jangka pendek dan hubungan kausalitas dari setiap variabel penelitian. Sehingga akan memberikan informasi yang lebih komprehensif kepada manajer investasi atau investor sebelum melakukan investasi pada pasar modal. Pengaruh jangka pendek berguna bagi investor yang cenderung melakukan transaksi dalam jangka waktu pendek. Penting untuk memahami pengaruh jangka panjang penting dari aset keuangan yang ada dalam portofolio investasi, karena hal tersebut akan mengurangi resiko portofolio investasi (Padliansyah et al., 2020). Hubungan kausalitas penting untuk mengetahui apakah ada hubungan dua arah dari setiap variabel yang ada dalam penelitian.

\section{Metode Penelitian}

\section{Unit Root Test}

Variabel penelitian pada analisis time series dihasilkan dari proses stasioner, dan data time series akan stasioner jika distribusi probabilitas tetap sama disetiap titik waktu (Das, 2019). Jika data time series tidak stasioner, maka dilanjutkan dengan analisis diferensial sampai data time series menjadi stasioner. Terdapat banyak pengujian untuk menilai apakah data pada variabel penelitian analisis time series stasioner atau tidak. Salah satu pengujian yang paling populer adalah Dickey-Fuller Test untuk unit root (Hill et al., 2018). Beberapa model estimasi unit root test adalah sebagai berikut (Hill et al., 2018):

Rumus 1. Model Dengan intersep dan tanpa trend waktu

$$
\Delta Y_{t}=\alpha+\gamma y_{t-1}+\sum_{s=1}^{p-1} \alpha s \Delta Y t-s+v t
$$

Rumus 2. Model Dengan intersep dan trend waktu

$$
\Delta Y_{t}=\alpha+\gamma y_{t-1}+\lambda t+\sum_{s=1}^{p-1} \alpha s \Delta Y t-s+v t
$$

Rumus 3. Model Tanpa intersep dan tanpa trend waktu

$$
\Delta Y_{t}=\gamma y_{t-1}+\sum_{s=1}^{p-1} \alpha s \Delta Y t-s+v t
$$

Dimana $\Delta$ menunjukkan diferensial orde pertama, $\alpha$ mewakili intersep pada model estimasi, $\gamma$ mewakili trend waktu, dan ${ }^{\alpha S}$ menunjukkan jeda (lag) periode optimal yang membuat residu ${ }^{v t}$ menjadi white-noise. Hipotesis yang dibangun pada unit root test adalah:

$\mathrm{H} 0: \gamma=0$ (terdapat unit root atau data time series tidak stasioner)

H1 $: \gamma<0$ (data time series stasioner)

Lag optimal seharusnya dimasukkan dalam mengestimasi model agar mengeliminasi autokorelasi dalam error. Terdapat beberapa signifikan estimasi lag optimal, pada sampel besar yang memiliki distribusi normal seperti kriteria Akaike information criterion (AIC) dan Schwarz criterion (SC) (Hill et al., 2018). Selain kedua kriteria tersebut, panjang lag optimal juga bisa ditentukan menggunakan kriteria Hannan-Quinn information criterion (HQ).

Rumus 4. Kriteria Akaike information criterion (AIC)

$$
A I C=\ln \left(\frac{55 E}{N}\right)+\frac{2 K}{N}
$$

Rumus 5. Kriteria Schwarz criterion (SC)

$$
S C=\ln \left(\frac{55 E}{N}\right)+\frac{K \ln (N)}{N}
$$

Rumus 6. Kriteria Hannan-Quinn information criterion (HQ)

$$
H Q=\ln \left(\frac{55 E}{N}\right)+\frac{K \ln (\ln N)}{N}
$$


Dimana $\mathrm{K}$ adalah periode lag, $\mathrm{N}$ mewakili jumlah sampel penelitian, dan SSE merupakan varians residual dari nilai kemungkinan maksimum. Akaike information criterion (AIC) lebih akurat untuk data bulanan, Schwarz criterion (SC) berfungsi lebih baik dengan ukuran sampel berapapun pada data triwulanan, dan Hannan-Quinn information criterion (HQ) berfungsi lebih baik pada data triwulanan dengan sampel lebih dari 120 (Das, 2019).

\section{Cointegration Test}

Kointegrasi dapat mengatasi masalah regresi palsu dalam deret waktu dan memeriksa apakah ada hubungan kausal antara variabel nonstasioner (Das, 2019). Variabel penelitian akan memiliki hubungan kointegrasi jika komponen-komponen dari variabel ini memiliki satu unit root dan ada kombinasi linear variabel yang stasioner. Hubungan kointegrasi dapat diartikan sebagai hubungan jangka panjang yang stabil antara komponen variabel dari data time series (Baltagi, 2011). Hubungan jangka panjang berada dalam keseimbangan ketika kombinasi linear dari variabel akar unit stasioner (Das, 2019). Pengujian kointegrasi pada penelitian ini menggunakan pengujian statistik nilai Eigen maksimum, sebagai berikut:

Rumus 7. Nilai Eigen Maksimum

$$
\lambda \operatorname{trance}(r, r+1)=-T \sum_{t=r+1}^{\mathrm{n}} \ln \left(1 \lambda^{A} i\right)
$$

Dimana $\mathrm{T}$ merupakan jumlah sampel penelitian, $\mathrm{r}$ merupakan jumlah kelompok vektor kointegrasi, sedangkan ${ }^{\lambda_{i}}$ merupakan estimasi nilai Eigen yang sesuai dengan distribusi chi-square yang sedang diperiksa.

$\mathrm{H} 0: \Pi=\mathrm{r}$ (tidak terdapat kointegrasi)

$\mathrm{H} 1: \Pi=\mathrm{r}+1$ (terdapat kointegrasi)

\section{Vector Auto-Regression (VAR)}

Metodologi vector auto-regression mirip dengan pemodelan persamaan simultan, dimana terdapat pertimbangan terhadap beberapa variabel endogen secara bersama-sama. Akan tetapi, setiap variabel endogen dijelaskan oleh nilai lag dari semua variabel endogen lainnya yang ada dalam estimasi model. Selain itu, pada estimasi model vector auto-regression tidak terdapat variabel eksogen (Gujarati \& Porter, 2009). Teori ekonomi mendefinisikan model vector auto-regression dengan hubungan kointegrasi dapat digunakan untuk menjelaskan keseimbangan jangka panjang atau pergerakan keseimbangan (Das, 2019).

Sebelum melakukan estimasi model vector auto-regression, harus dipastikan bahwa masalah indentifikasi telah selesai yang artinya bahwa parameter atau set parameter dapat diperkirakan secara konsisten. Dalam pencapaian indentifikasi, dilakukan pembatasan dengan mengecualikan beberapa variabel yang ada pada persamaan dan bisa muncul pada persamaan lain pada suatu sistem (Gujarati, 2014). Model VAR adalah sebagai berikut:

Rumus 8. Model Vector Auto-Regression

$$
Y_{\mathrm{t}}=\alpha+\sum_{\mathrm{i}=1}^{\mathrm{p}} \beta i Y_{\mathrm{t}-\mathrm{i}}+\varepsilon_{\mathrm{t}}
$$

\section{Granger Causality}

Model regresi menunjukkan hubungan statistik antara satu variabel dengan variabel yang lainnya, bukan hubungan sebab akibat antara setiap variabel. Granger causality diperkenalkan oleh Granger (1969) dengan menggunakan model Vector Auto-Regression (VAR) (Das, 2019). Jika terdapat dua variabel $\mathrm{x}$ dan y pada penelitian, granger causality dilakukan untuk mengetahui apakah perubahan variabel $x$ mempengaruhi perubahan y atau sebaliknya apakah perubahan variabel y mempengaruhi perubahan $\mathrm{x}$. Pengujian granger causality mengasumsikan bahwa informasi yang terkandung pada data time series relevan pada setiap variabel penelitian (Gujarati \& Porter, 2009). Analisis granger causality pada penelitian ini menggunakan pasangan model estimasi sebagai berikut:

Rumus 9. Model Granger Causality 1

$$
x_{t}=\sum_{\mathrm{i}=1}^{\mathrm{n}} \alpha_{\mathrm{i}} y_{t-\mathrm{i}}+\sum_{j=1}^{\mathrm{n}} \beta_{j} x_{t-j}+u_{1 t}
$$

Hipotesis yang dibangun pada model estimasi yang pertama di atas adalah sebagai berikut:

$\mathrm{H} 0: \beta=0$ (tidak terdapat kausalitas)

$\mathrm{H} 1: \beta \neq 0$ (terdapat kausalitas)

Rumus 10. Model Granger Causality 2

$$
y_{t}=\sum_{i=1}^{\mathrm{m}} \lambda_{i} y_{t-i}+\sum_{j=1}^{\mathrm{m}} \delta_{j} x_{t-j}+u_{2 t}
$$

Hipotesis yang dibangun pada model estimasi yang kedua adalah sebagai berikut:

$\mathrm{H} 0:{ }^{\delta}=0$ (tidak terdapat kausalitas)

$\mathrm{H} 1:^{\delta} \neq 0$ (terdapat kausalitas)

\section{Impulse Responses}

Fungsi impulse responses digunakan untuk mengukur efek guncangan eksternal variabel time series dalam waktu t (Das, 2019). Sedangkan menurut Hill et al (2018), impulse responses digunakan untuk mengukur efek guncangan pada jalur penyesuaian variabel yang ada pada penelitian. Pengujian impulse responses dilakukan untuk mengetahui apakah terdapat pengaruh jangka pendek maupun jangka panjang pada variabel penelitian dengan melihat periode pengamatan yang telah ditentukan sebelumnya. Model estimasi reduksi 
dari Vector Auto-Regression (VAR) bivariat (Das, 2019) adalah sebagai berikut:

Rumus 11. Model Estimasi Reduksi VAR Impulse Responses

$$
\begin{gathered}
\left(I-\Pi_{1} L\right) x_{t}=\Pi_{0}+e_{t} \\
x_{t}=\left(I-\prod_{1} L\right)^{-1} \prod_{0}+\left(I-\Pi_{1} L\right)^{-1} \mathrm{e}_{t}, \text { atau } \\
x_{t}=A+\sum_{i=0}^{\infty} \prod_{1}^{i} e_{t-1}^{i}
\end{gathered}
$$

VMA $(\infty)$ proses yang menunjukkan bahwa pengamatan $x_{t}$ merupakan kombinasi linear dari guncangan $e_{t}$. Hal tersebut dapat memberikan informasi tentang respon ${ }^{x_{t}}$ terhadap guncangan unit dari $e_{t}$ (Das, 2019).

\section{Hasil dan Pembahasan}

\section{Deskripsi Data}

Penelitian ini menggunakan data harian selama 10 tahun terakhir mulai dari tanggal 4/1/2010 sampai dengan tanggal 30/12/2019. LQ45 adalah data indeks harga saham Jakarta Stock Exchange LQ45 pada saat penutupan. DJI merupakan data indeks harga saham Dow Jones Industrial Average yang ada di United States of America (USA) pada saat penutupan. USD/IDR merupakan data nilai kurs dolar terhadap rupiah pada saat penutupan. WTI merupakan data harga komoditas minyak mentah duniah dari Crude Oil WTI Futures pada saat penutupan. GOLD merupakan data harga emas dunia atau Gold Contract pada saat penutupan. Data LQ45, DJI, USD/IDR, WTI dan GOLD diperoleh dari website investing.com.

TABEL 1

SUMBER DATA

\begin{tabular}{lll}
\hline Kode Variable & Nama Variable & Website \\
\hline LQ45 & Jakarta Stock Exchange LQ45 & Investing.com \\
DJI & Dow Jones Industrial Average & Investing.com \\
USD/IDR & Kurs Dolar terhadap Rupiah & Investing.com \\
WTI & Crude Oil WTI Futures & Investing.com \\
GOLD & Gold Contract & Investing.com \\
\hline
\end{tabular}

Sumber: investing.com

TABEL 2

STATISTIK DESKRIPTIF

\begin{tabular}{lccccc}
\hline & LQ45 & DJI & USD/IDR & WTI & GOLD \\
\hline Mean & 824.1182 & 17764.88 & 11867.10 & 72.06559 & 1386.355 \\
Median & 835.9150 & 17145.35 & 12717.95 & 69.56000 & 1357.600 \\
Maximum & 1132.190 & 28645.26 & 15234.95 & 112.8600 & 1888.700 \\
Minimum & 479.1700 & 9686.480 & 8459.999 & 26.55000 & 1052.200 \\
Std. Dev. & 141.1138 & 5140.771 & 2092.067 & 21.89300 & 163.2161 \\
Skewness & -0.260926 & 0.395989 & -0.324434 & 0.071272 & 0.626049 \\
Kurtosis & 2.248663 & 2.018569 & 1.502305 & 1.622828 & 2.871875 \\
\hline
\end{tabular}

DLQ45

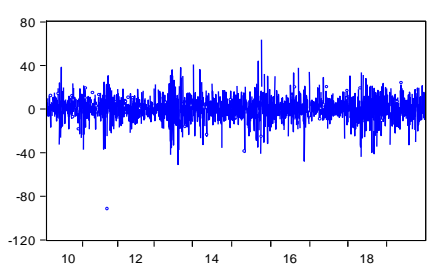

DDJI

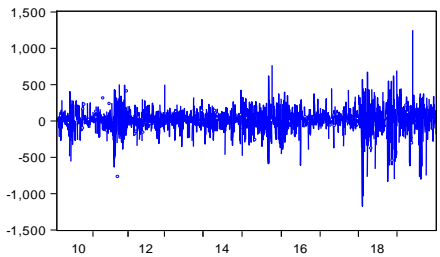

DWTI

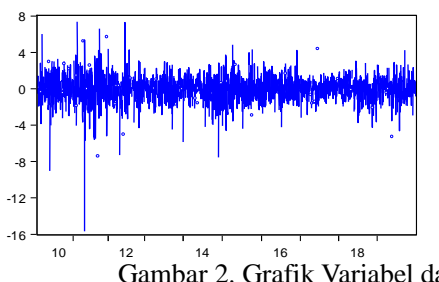

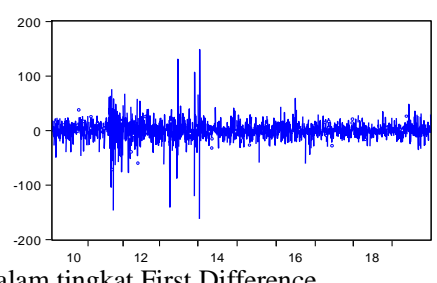

Sumber: hasil olah data Eviews 10 


\section{Unit Root Test}

Unit root test dilakukan untuk mengetahui pada tingkat apa data pada setiap variabel penelitian menjadi stasioner. Hasil unit root test dapat dilihat pada tabel sebagai berikut:

TABEL 3

HASIL UNIT ROOT TEST

\begin{tabular}{|c|c|c|c|c|c|c|}
\hline & \multicolumn{2}{|c|}{ Tingkat Level } & \multicolumn{4}{|c|}{ Tingkat First Difference } \\
\hline & $\begin{array}{l}\mathrm{ADF} \\
\text { t-Statistic }\end{array}$ & Critical Value & Prob. & $\begin{array}{l}\text { ADF } \\
\text { t-Statistic }\end{array}$ & Critical Value & Prob. \\
\hline LQ45 & -2.191801 & -2.862768 & 0.2095 & -25.74473 & -2.862768 & 0.0000 \\
\hline DJI & 0.068523 & -2.862768 & 0.9633 & -46.15737 & -2.862768 & 0.0001 \\
\hline USD/IDR & -0.830545 & -2.862768 & 0.8097 & -40.74186 & -2.862768 & 0.0000 \\
\hline WTI & -1.434090 & -2.862768 & 0.5669 & -48.04939 & -2.862768 & 0.0001 \\
\hline GOLD & -2.372076 & -2.862768 & 0.1499 & -48.98320 & -2.862768 & 0.0001 \\
\hline
\end{tabular}

Sumber: hasil olah data eviews 10

Berdasarkan hasil unit root test pada tabel 3 di atas, pada tingkat level data pada semua variabel memiliki nilai ADF t-statistic yang lebih besar dari critical value $5 \%$ dan nilai probabilitas setiap variabel lebih besar dari $\alpha=0,05$ sehingga $\mathrm{H} 0$ diterima dan $\mathrm{H} 1$ ditolak. Data pada tingkat level mengandung akar unit.

Sedangkan pada tingkat first difference data pada semua variabel memiliki nilai ADF t-statistic yang lebih kecil dari critical value 5\% dan nilai probabilitas setiap variabel lebih kecil dari $\alpha=0,05$ sehingga $H 0$ ditolak dan $\mathrm{H} 1$ diterima atau data tidak mengandung akar unit. Sehingga dapat disimpulkan bahwa data pada variabel penelitian stasioner pada tingkat first difference.

\section{Lag Optimal}

Sebelum melakukan tes kointegrasi perlu ditentukan panjang lag optimal untuk menghitung jumlah vektor terintegrasi. Panjang lag optimal maksimal yang dipilih adalah 8 , dengan berdasarkan kriteria Akaike information criterion (AIC), Schwarz information criterion (SC) dan Hannan-Quinn information criterion (HQ).

TABEL 4

LAG OPTIMAL

\begin{tabular}{lllllll}
\hline Lag & LogL & LR & FPE & AIC & SC & HQ \\
\hline 0 & -43517.95 & NA & $4.14 \mathrm{e}+12$ & 43.24188 & 43.25581 & 43.24699 \\
1 & -43391.71 & 251.7360 & $3.75 \mathrm{e}+12^{*}$ & $43.14129^{*}$ & $43.22485^{*}$ & $43.17196^{*}$ \\
2 & -43373.60 & 36.01520 & $3.77 \mathrm{e}+12$ & 43.14814 & 43.30134 & 43.20437 \\
3 & -43351.94 & 42.96487 & $3.79 \mathrm{e}+12$ & 43.15146 & 43.37431 & 43.23326 \\
4 & -43336.39 & 30.78855 & $3.82 \mathrm{e}+12$ & 43.16084 & 43.45333 & 43.26820 \\
5 & -43317.30 & $37.69186^{*}$ & $3.84 \mathrm{e}+12$ & 43.16671 & 43.52884 & 43.29963 \\
6 & -43300.02 & 34.01463 & $3.87 \mathrm{e}+12$ & 43.17439 & 43.60615 & 43.33287 \\
7 & -43287.75 & 24.10532 & $3.92 \mathrm{e}+12$ & 43.18703 & 43.68844 & 43.37108 \\
8 & -43274.58 & 25.79563 & $3.97 \mathrm{e}+12$ & 43.19879 & 43.76984 & 43.40840 \\
\hline \multicolumn{7}{c}{ * indicates lag order selected by the criterion } \\
$c$
\end{tabular}

Berdasarkan tabel 4 di atas panjang lag optimal data adalah 1. Hal tersebut sesuai dengan kriteria Akaike information criterion (AIC), Schwarz information criterion (SC) dan Hannan-Quinn information criterion (HQ).

\section{Cointegration Test}

Tes kointegrasi dilakukan untuk mengetahui pengaruh jangka panjang yang ada pada setiap variabel penelitian. Hasil cointegration test pada penelitian ini dapat dilihat pada tabel sebagai berikut: 
TABEL 5

HASIL COINTEGRATION TEST

\begin{tabular}{|c|c|c|c|c|}
\hline No. of CE(s) & Trace statistic & $\begin{array}{l}5 \% \text { Critical } \\
\text { value }\end{array}$ & $\begin{array}{l}\text { Max-eigen } \\
\text { statistic }\end{array}$ & $\begin{array}{l}5 \% \text { Critical } \\
\text { value }\end{array}$ \\
\hline \multicolumn{5}{|l|}{ None } \\
\hline \multicolumn{5}{|l|}{ No Intercept and no trend } \\
\hline$r=0$ & 4396.796 & 60.06141 & 1016.417 & 30.43961 \\
\hline $\mathrm{r} \leq 1$ & 3380.379 & 40.17493 & 914.8322 & 24.15921 \\
\hline$r \leq 2$ & 2465.547 & 24.27596 & 878.5154 & 17.79730 \\
\hline$r \leq 3$ & 1587.031 & 12.32090 & 850.3304 & 11.22480 \\
\hline$r \leq 4$ & 736.7007 & 4.129906 & 736.7007 & 4.129906 \\
\hline \multicolumn{5}{|l|}{ Intercept and no trend } \\
\hline$r=0$ & 4417.680 & 76.97277 & 1019.486 & 34.80587 \\
\hline$r \leq 1$ & 3398.195 & 54.07904 & 929.7957 & 28.58808 \\
\hline$r \leq 2$ & 2468.399 & 35.19275 & 880.7355 & 22.29962 \\
\hline$r \leq 3$ & 1587.663 & 20.26184 & 850.7920 & 15.89210 \\
\hline$r \leq 4$ & 736.8714 & 9.164546 & 736.8714 & 9.164546 \\
\hline \multicolumn{5}{|l|}{ Linear } \\
\hline \multicolumn{5}{|l|}{ Intercept and no trend } \\
\hline $\mathrm{r}=0$ & 4417.679 & 69.81889 & 1019.485 & 33.87687 \\
\hline $\mathrm{r} \leq 1$ & 3398.194 & 47.85613 & 929.7957 & 27.58434 \\
\hline$r \leq 2$ & 2468.398 & 29.79707 & 880.7355 & 21.13162 \\
\hline$r \leq 3$ & 1587.663 & 15.49471 & 850.7920 & 14.26460 \\
\hline$r \leq 4$ & 736.8708 & 3.841466 & 736.8708 & 3.841466 \\
\hline \multicolumn{5}{|l|}{ Intercept and trend } \\
\hline$r=0$ & 4419.416 & 88.80380 & 1020.277 & 38.33101 \\
\hline$r \leq 1$ & 3399.139 & 63.87610 & 929.9071 & 32.11832 \\
\hline$r \leq 2$ & 2469.232 & 42.91525 & 881.0735 & 25.82321 \\
\hline$r \leq 3$ & 1588.158 & 25.87211 & 851.0531 & 19.38704 \\
\hline$r \leq 4$ & 737.1049 & 12.51798 & 737.1049 & 12.51798 \\
\hline
\end{tabular}

Sumber: hasil olah data eviews 10

Berdasarkan hasil cointegration test pada tabel di atas, nilai trace statistic lebih besar dari nilai critical value (5\%) pada $\mathrm{r}=0$ (none), $\mathrm{r} \leq 1$ (at most 1 ), $\mathrm{r} \leq 2$ (at most 2), $r \leq 3$ (at most 3), dan $r \leq 4$ (at most 4). Hal tersebut sejalan dengan hasil nilai max-eigen statistic yang lebih besar dari nilai critical value (5\%). Sehingga HO ditolak dan $\mathrm{H} 1$ diterima, atau terdapat hubungan kointegrasi pada setiap variabel penelitian. Sehingga dapat disimpulkan bahwa terdapat pengaruh jangka panjang antara Indeks Dow Jones, Kurs Dolar, Minyak Dunia dan Emas terhadap Indeks Saham Indonesia LQ45.

\section{Granger Causality}

Analisis granger causality dilakukan untuk mengetahui hubungan kausalitas dua arah pada setiap variabel penelitian. Hasil analisis granger causality dapat dilihat pada tabel sebagai berikut:

TABEL 6

HASIL ANALISIS GRANGER CAUSALITy

\begin{tabular}{llll}
\hline Null Hypothesis: & F-Stat. & Prob. & Dec. \\
\hline$\Delta$ DJI does not Granger Cause $\Delta$ LQ45 & 126.724 & 0.0000 & H0 ditolak, H1 diterima \\
$\Delta$ LQ45 does not Granger Cause $\Delta$ DJI & 1.11283 & 0.2916 & H0 diterima, H1 ditolak \\
$\Delta$ USD/IDR does not Granger Cause $\Delta$ LQ45 & 4.60583 & 0.0320 & H0 ditolak, H1 diterima \\
$\Delta$ LQ45 does not Granger Cause $\Delta$ USD/IDR & 11.7706 & 0.0006 & H0 ditolak, H1 diterima \\
$\Delta$ WTI does not Granger Cause $\Delta$ LQ45 & 19.2672 & 0.0000 & H0 ditolak, H1 diterima \\
$\Delta$ LQ45 does not Granger Cause $\Delta$ WTI & 0.02876 & 0.8654 & H0 diterima, H1 ditolak \\
$\Delta$ GOLD does not Granger Cause $\Delta$ LQ45 & 5.02267 & 0.0251 & H0 ditolak, H1 diterima \\
$\Delta$ LQ45 does not Granger Cause $\Delta$ GOLD & 8.83950 & 0.0030 & H0 ditolak, H1 diterima \\
\hline
\end{tabular}

Sumber: hasil olah data eviews 10

Berdasarkan hasil analisis granger causality pada tabel 6 di atas, variabel USD/IDR dan GOLD memiliki hubungan kausalitas dua arah terhadap variabel LQ45. Hal tersebut dapat diartikan bahwa setiap perubahan LQ45 akan mempengaruhi USD/IDR dan GOLD, sebaliknya setiap perubahan USD/IDR dan GOLD juga akan mempengaruhi LQ45.
Sedangkan variabel DJI dan WTI hanya memiliki hubungan satu arah terhadap variabel LQ45. Artinya bahwa setiap perubahan DJI akan mempengaruhi LQ45 dan setiap perubahan WTI akan mempengaruhi LQ45. Walaupun hasil tersebut menunjukan adanya hubungan yang mempengaruhi pada setiap variabel, tetapi uji hubungan kausalitas hanya menjelaskan pengaruh pada setiap variabel tanpa bisa menjelaskan 
pengaruh jangka panjang seperti yang terdapat pada uji ko-integrasi Johansen atau uji respon impuls yang dapat menjelaskan hubungan jangka pendek pada setiap variabel (Padliansyah et al., 2020).

\section{Impulse Responses}

Pengujian impulse responses dilakukan untuk melihat reaksi setiap variabel dari gangguan variabel lainnya dilihat dari periode pengamatan yang telah ditentukan sebelumnya. Artinya bahwa impulse responses dilakukan untuk mengetahui apakah terdapat pengaruh jangka pendek maupun jangka panjang dari setiap variabel. Hasil pengujian impulse responses dapat dilihat pada tabel dan gambar sebagai berikut:

TABEL 7

REAKSI INDEKS SAHAM LQ45 DARI GANGGUAN VARIABEL YANG LAIN

\begin{tabular}{cccccc}
\hline \multicolumn{7}{c}{ Response of $\Delta$ LQ45 } \\
\hline Period & $\Delta$ LQ45 & $\Delta$ DJI & $\Delta$ USD/IDR & $\Delta$ WTI & $\Delta$ GOLD \\
\hline 1 & 10.47459 & 0.000000 & 0.000000 & 0.000000 & 0.000000 \\
2 & 0.311123 & 2.616229 & -0.348224 & 0.272732 & 0.530115 \\
3 & -0.712161 & -0.538615 & 0.099718 & -0.128545 & -0.123565 \\
4 & -0.016580 & -0.223087 & -0.020004 & 0.050002 & 0.027261 \\
5 & 0.042776 & 0.059029 & 0.011765 & -0.004700 & -0.007022 \\
6 & 0.000448 & 0.008934 & -0.000169 & -0.006993 & $-2.51 \mathrm{E}-06$ \\
7 & -0.002897 & -0.003076 & -0.000822 & 0.002244 & 0.000280 \\
8 & $4.60 \mathrm{E}-06$ & -0.000646 & 0.000130 & $8.58 \mathrm{E}-05$ & -0.000231 \\
9 & 0.000186 & 0.000226 & $1.03 \mathrm{E}-05$ & -0.000109 & $9.84 \mathrm{E}-05$ \\
10 & $-1.20 \mathrm{E}-06$ & $4.41 \mathrm{E}-05$ & $3.30 \mathrm{E}-06$ & $3.53 \mathrm{E}-07$ & $-1.21 \mathrm{E}-05$ \\
\hline
\end{tabular}

TABEL 8

REAKSI INDEK DOW JONES DARI GANGGUAN VARIABEL YANG LAIN

\begin{tabular}{cccccc}
\hline & \multicolumn{3}{c}{ Response of $\Delta$ DJI } \\
\hline Period & $\Delta$ LQ45 & $\Delta$ DJI & $\Delta$ USD/IDR & $\Delta$ WTI & $\Delta$ GOLD \\
\hline 1 & 32.67278 & 165.6127 & 0.000000 & 0.000000 & 0.000000 \\
2 & 3.335509 & -5.550205 & -8.522336 & -1.361984 & -1.807106 \\
3 & 0.241951 & -2.073988 & -3.325790 & 4.691302 & 3.079110 \\
4 & 0.361699 & 0.332225 & 0.441316 & -0.690001 & -0.252842 \\
5 & 0.096805 & -0.063793 & -0.074138 & -0.176591 & 0.159744 \\
6 & -0.020977 & 0.017782 & 0.009647 & 0.048002 & -0.035417 \\
7 & -0.006998 & -0.017295 & 0.002717 & -0.011248 & -0.007547 \\
8 & $-9.57 \mathrm{E}-05$ & 0.001993 & 0.000147 & 0.001900 & 0.003264 \\
9 & 0.000268 & 0.000413 & 0.000559 & -0.000290 & -0.001058 \\
10 & $-1.85 \mathrm{E}-05$ & $-8.97 \mathrm{E}-05$ & -0.000192 & $1.13 \mathrm{E}-05$ & 0.000192 \\
\hline
\end{tabular}

Sumber: hasil olah data eviews 10

TABEL 9

REAKSI KURS DOLAR DARI GANGGUAN VARIABEL YANG LAIN

\begin{tabular}{cccccc}
\hline \multicolumn{5}{c}{ Response of $\Delta$ USD/IDR } \\
\hline Period & $\Delta$ LQ45 & $\Delta$ DJI & $\Delta$ USD/IDR & $\Delta$ WTI & $\Delta$ GOLD \\
\hline 1 & -17.34219 & -6.090188 & 47.56884 & 0.000000 & 0.000000 \\
2 & -6.044402 & -9.460780 & 2.283243 & -0.185749 & -2.770558 \\
3 & -1.176377 & 1.088417 & -0.148114 & 1.361829 & 0.275575 \\
4 & 0.211323 & 0.188922 & 0.138410 & -0.259708 & -0.181791 \\
5 & 0.102724 & 0.059251 & -0.091431 & 0.044940 & 0.096656 \\
6 & -0.004035 & 0.020915 & $-5.13 \mathrm{E}-05$ & 0.012066 & -0.010446 \\
7 & -0.003024 & -0.011844 & -0.002086 & -0.005052 & 0.002261 \\
8 & 0.000574 & 0.000554 & $9.73 \mathrm{E}-05$ & 0.001216 & 0.000769 \\
9 & 0.000251 & 0.000226 & 0.000229 & -0.000446 & -0.000457 \\
10 & $-5.87 \mathrm{E}-05$ & $-4.44 \mathrm{E}-06$ & $-6.10 \mathrm{E}-05$ & $2.51 \mathrm{E}-05$ & $9.84 \mathrm{E}-05$ \\
\hline
\end{tabular}

Sumber: hasil olah data eviews 10 
TABEL 10

REAKSI MINYAK DUNIA DARI GANGGUAN VARIABEL YANG LAIN

\begin{tabular}{cccccc}
\hline \multicolumn{5}{c}{ Response of $\Delta$ WTI } \\
\hline Period & $\Delta$ LQ45 & $\Delta$ DJI & $\Delta$ USD $/$ IDR & $\Delta$ WTI & $\Delta$ GOLD \\
\hline 1 & 0.174272 & 0.433803 & -0.029542 & 1.421739 & 0.000000 \\
2 & -0.020932 & 0.024145 & -0.015265 & -0.112069 & 0.022387 \\
3 & -0.004331 & -0.004676 & -0.026864 & 0.009899 & 0.063843 \\
4 & 0.009022 & -0.002354 & 0.000835 & 0.001434 & -0.010615 \\
5 & 0.001941 & 0.000713 & -0.001790 & -0.001879 & 0.001625 \\
6 & -0.000549 & 0.000580 & 0.000358 & 0.000222 & $1.27 \mathrm{E}-08$ \\
7 & -0.000101 & -0.000432 & $3.50 \mathrm{E}-05$ & $-9.84 \mathrm{E}-05$ & -0.000149 \\
8 & $1.75 \mathrm{E}-05$ & $3.48 \mathrm{E}-05$ & $-1.22 \mathrm{E}-05$ & $3.86 \mathrm{E}-05$ & $3.95 \mathrm{E}-05$ \\
9 & $2.75 \mathrm{E}-06$ & $1.77 \mathrm{E}-05$ & $1.12 \mathrm{E}-05$ & $-1.02 \mathrm{E}-05$ & $-1.24 \mathrm{E}-05$ \\
10 & $-1.22 \mathrm{E}-06$ & $-3.94 \mathrm{E}-06$ & $-2.68 \mathrm{E}-06$ & $1.22 \mathrm{E}-07$ & $2.41 \mathrm{E}-06$ \\
\hline
\end{tabular}

Sumber: hasil olah data eviews 10

TABEL 11

REAKSI EMAS DARI GANGGUAN VARIABEL YANG LAIN

\begin{tabular}{cccccc}
\hline \multicolumn{5}{c}{ Response of $\Delta$ WTI } \\
\hline Period & $\Delta$ LQ45 & $\Delta$ DJI & $\Delta$ USD/IDR & $\Delta$ WTI & $\Delta$ GOLD \\
\hline 1 & 1.218626 & -0.343962 & -2.353145 & 3.120414 & 16.24115 \\
2 & 1.075925 & -0.077332 & 0.205700 & 0.178949 & -1.575622 \\
3 & 0.191946 & -0.209452 & -0.451325 & -0.336832 & 0.261497 \\
4 & -0.044413 & 0.115637 & 0.052195 & 0.051856 & 0.010383 \\
5 & -0.002026 & -0.053554 & 0.010685 & -0.029123 & -0.029283 \\
6 & 0.000111 & 0.004927 & -0.003192 & 0.007155 & 0.007691 \\
7 & -0.000652 & 0.001547 & 0.002103 & -0.001107 & -0.002578 \\
8 & $-5.52 \mathrm{E}-05$ & -0.000741 & -0.000409 & -0.000102 & 0.000452 \\
9 & $7.70 \mathrm{E}-06$ & 0.000184 & $3.64 \mathrm{E}-05$ & 0.000180 & $-2.41 \mathrm{E}-05$ \\
10 & $1.21 \mathrm{E}-05$ & $-2.30 \mathrm{E}-05$ & $4.27 \mathrm{E}-06$ & $-5.52 \mathrm{E}-05$ & $-1.86 \mathrm{E}-05$ \\
\hline
\end{tabular}

Sumber: hasil olah data eviews 10

Response to Cholesky One S.D. (d.f. adjusted) Innovations

Response of DLQ45 to Innovations
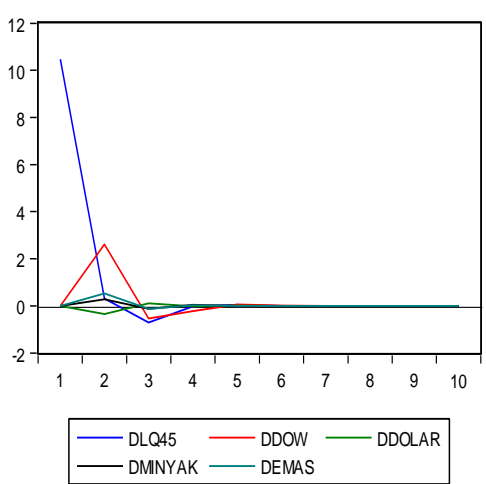

Response of DDOW to Innovations
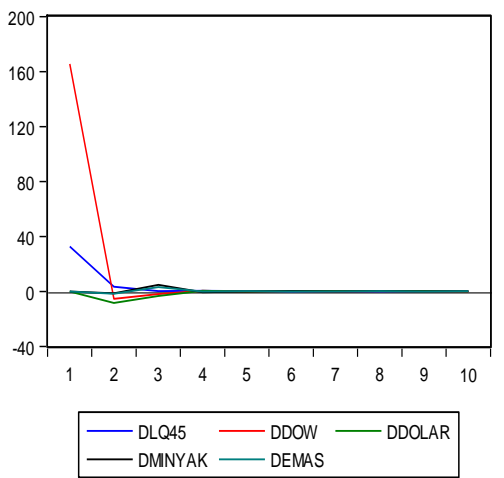

Response of DDOLAR to Innovations

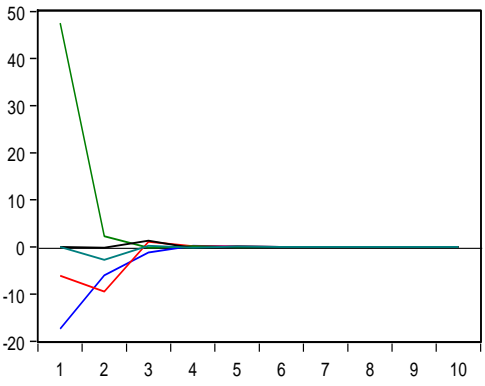

DLQ45 DDOW DDOLAR
Response of DMINYAK to Innovations

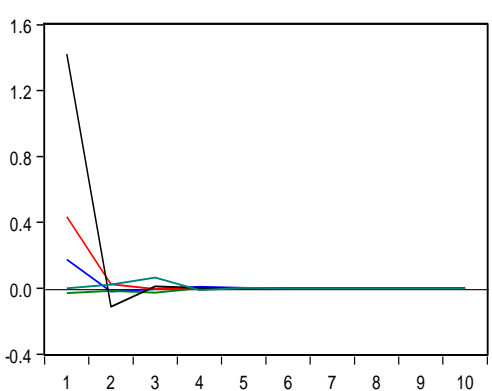

Response of DEMAS to Innovations

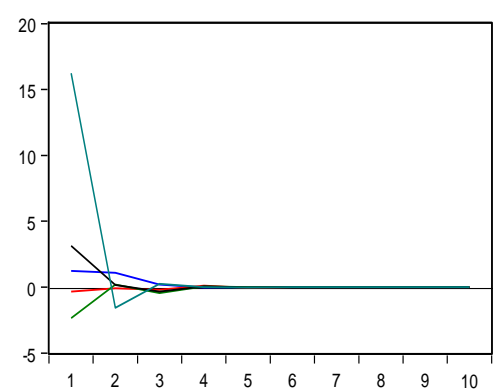

- DLQ45 - DDOW - DDOLAR
DMINYAK - DEMAS

Gambar 3. Impulse Responses

Sumber: hasil olah data eviews 10 
Berdasarkan hasil pengujian impulse responses pada tabel 7 sampai dengan tabel 10 dan pada gambar 3, setiap variabel bereaksi terhadap gangguan variabel lainnya yang ada pada penelitian. Dengan 10 periode pengamatan yang digunakan dalam penelitian, terdapat pengaruh pada setiap variabel terhadap variabel lainnya pada setiap periode pengamatan.

Setiap variabel memiliki pengaruh yang besar terhadap variabel lainnya pada awal periode pengamatan, kemudian semakin kecil pada periode pengamatan selanjutnya. Sehingga dapat disimpulkan bahwa terdapat pengaruh jangka pendek dan jangka panjang antara Indeks Dow Jones, Kurs Dolar, Minyak Dunia dan Emas terhadap Indeks Saham Indonesia LQ45. Hasil pengujian impulse responses mendukung hasil cointegration test yang dilakukan sebelumnya, bahwa terdapat pengaruh jangka panjang antara Indeks Dow Jones, Kurs Dolar, Minyak Dunia dan Emas terhadap Indeks Saham Indonesia LQ45.

\section{Kesimpulan}

Cointegration test, granger causality dan impulse responses dilakukan untuk mengetahui pengaruh jangka pendek dan jangka panjang antara Indeks Dow Jones, Kurs Dolar, Minyak Dunia dan Emas terhadap Indeks Saham Indonesia LQ45. Berdasarkan hasil dan pembahasan, data pada setiap variabel penelitian stasioner pada tingkat first difference.

Hasil cointegration test menunjukkan bahwa terdapat hubungan kointegrasi pada setiap varibel penelitian. Dapat diartikan bahwa terdapat pengaruh jangka panjang antara Indeks Dow Jones, Kurs Dolar, Minyak Dunia dan Emas terhadap Indeks Saham Indonesia LQ45.

Hasil analisis granger causality menunjukkan bahwa variabel kurs dolar dan emas memiliki hubungan kausalitas dua arah terhadap variabel indeks saham LQ45. Hal tersebut dapat diartikan bahwa setiap perubahan indeks saham LQ45 akan mempengaruhi kurs dolar dan emas, sebaliknya setiap perubahan kurs dolar dan emas juga akan mempengaruhi indeks saham LQ45. Sedangkan variabel indek Dow Jones dan minyak dunia hanya memiliki hubungan satu arah terhadap variabel indeks saham LQ45. Artinya bahwa setiap perubahan indeks Dow Jones akan mempengaruhi indeks saham LQ45 dan setiap perubahan minyak dunia akan mempengaruhi indeks saham LQ45. Akan tetapi, setiap perubahan indek saham LQ45 tidak akan mempengaruhi varibel indeks Dow Jones dan minyak dunia.

Hasil pengujian impulse responses menunjukkan bahwa dari 10 periode pengamatan yang telah ditentukan, setiap variabel bereaksi terhadap gangguan variabel lainnya yang ada pada penelitian. Setiap variabel memiliki pengaruh yang besar terhadap variabel lainnya pada awal periode pengamatan, kemudian semakin kecil pada periode pengamatan selanjutnya. Sehingga dapat disimpulkan bahwa terdapat pengaruh jangka pendek dan jangka panjang antara Indeks Dow Jones, Kurs Dolar, Minyak Dunia dan Emas terhadap Indeks Saham Indonesia LQ45.

Penelitian ini dapat menjadi sumber informasi bagi manajer investasi untuk memberikan rekomendasi kepada investor pasar modal, sehingga dapat menambah diversifikasi portofolio investasi dan pada akhirnya dapat mengurangi resiko investasi. Selain itu, penelitian ini bisa memberikan informasi tentang alternatif investasi kepada calon investor yang ingin berinvestasi pada pasar modal Indonesia khususnya dengan memilih saham-saham yang ada pada Indeks Saham LQ45.

\section{Daftar Pustaka}

A. Antonius, S. (2019). Pengaruh Inflasi, Suku Bunga As, Harga Emas, Harga Minyak Bumi, Inflasi As Dan Kurs Rupiah Terhadap Indeks Sektoral Di Indonesia. Jurnal Manajemen Bisnis Dan Kewirausahaan, 3(3).

B. Baltagi, B. H. (2011). Econometrics (Fifth Edit). Springer Texts in Business and Economics. https://doi.org/10.1007/978-3-642-20059-5

C. Budiarto, A. (2017). Pengaruh Financial Literacy, Overconfidence, Regret Aversion Bias, Danrisk Tolerance Terhadap Keputusan Investasi (Studi pada investor PT. Sucorinvest Central Gani Galeri Investasi BEI Universitas Negeri Surabaya). Jurnal Ilmu Manajemen (JIM), 5(2).

D. Das, P. (2019). Econometrics in Theory and Practice: Analysis of Cross Section, Time Series and Panel Data with Stata 15.1. Springer Nature.

E. Gujarati, D. N. (2014). Econometrics by Example (Second edi). Palgrave.

F. Gujarati, D. N., \& Porter, D. C. (2009). Basic Econometrics (Fifth Edit). Mc Graw-Hill.

G. Hill, R. C., Griffiths, W. E., \& Lim, G. C. (2018). Principles of econometrics. John Wiley \& Sons.

H. Ismanto, H. (2016). Analisis Value at Risk dalam Pembentukan Portofolio Optimal (Studi Empiris pada Saham-Saham yang Tergabung Dalam LQ45). 
I. Jannah, M., \& Nurfauziah, N. (2018). Analisis Pengaruh Nilai Tukar Rupiah, Tingkat Suku Bunga SBI (Bi Rate) dan Harga Emas Dunia Terhadap Indeks LQ45 Di Bursa Efek Indonesia. Jurnal Manajemen Maranatha, 17(2), 103-110.

J. Larasati, D., Irwanto, A. K., \& Permanasari, Y. (2016). Analisis strategi optimalisasi portofolio saham LQ 45 (pada Bursa Efek Indonesia Tahun 2009-2011). Jurnal Manajemen Dan Organisasi, 4(2), 163-171.

K. Padliansyah, R., Juliana, A., \& Hasiara, L. O. (2020). Hubungan Interaktif Antara Harga Logam Mulia dan Jakarta Islamic Stock Index. Moneter-Jurnal Akuntansi Dan Keuangan, 7(1), 37-47.

L. Pradikasari, E., \& Isbanah, Y. (2018). Pengaruh financial literacy, illusion of control, overconfidence, risk tolerance, dan risk perception terhadap keputusan investasi pada mahasiswa di Kota Surabaya. Jurnal Ilmu Manajemen (JIM), 6(4).

M. Rohmawati, I. (2017). Pengaruh Volume Perdagangan, Dividend Payout Ratio Dan Inflasi Terhadap Volatilitas Harga Saham Pada Perusahaan Yang Terdaftar Dalam Indeks LQ45 Tahun 2011-2015. Jurnal Pendidikan Dan Ekonomi, 6(1), 38-45.

N. Syarif, M. M., \& Asandimitra, N. (2015). Pengaruh Indikator Makro Ekonomi Dan Faktor Global Terhadap Indeks Harga Saham Gabungan (Ihsg). Competence: Journal of Management Studies, 9(2).

O. Untono, M. (2015). Analisis Pengaruh Pertumbuhan Ekonomi, Inflasi, Nilai Tukar, Indek DJIA, dan Harga Minyak Dunia Terhadap Indek Harga Saham Gabungan. Parsimonia-Jurnal Ekonomi Dan Bisnis, 2(2), 1-12.

P. Wulansari, W., \& Yonnedi, E. (2015). Volatilitas Harga Saham Pasar Modal Indonesia: Studi Pada Indeks LQ45 Periode 30 Desember 2011-30 Juni 2014. Jurnal Akuntansi Dan Governance Andalas, 1(1), 83-97. 